http://dx.doi.org/10.1590/0370-44672019730134

Thiago Fávero de Oliveira Machado ${ }^{1,2}$

https://orcid.org/0000-0002-4115-7990

Geraldo Luciano de Oliveira Marques ${ }^{1,3}$

https://orcid.org/0000-0003-1347-2624

Marcos Lamha Rocha ${ }^{1,4}$

https://orcid.org/0000-0002-0581-9176

${ }^{1}$ Universidade Federal de Juiz de Fora - UFJF, Departamento de Geotecnia e Transportes, Juiz de Fora - Minas Gerais - Brasil.

E-mails: ${ }^{2}$ thiago.favero@engenharia.ufjf.br, 33eraldo.marques@ufjf.edu.br, ${ }^{4}$ marcoslr94@gmail.com

\section{Flexible pavement overlay design of UFJF ring road based on the new Brazilian mechanistic-empirical pavement design method}

\section{Abstract}

The procedures for design and reinforcement projects regarding flexible pavements available in Brazil are mostly based on empirical models developed from studies carried out in specific localities, and therefore, should only be used in cases where equivalent climatic and traffic conditions are observed. The national highway agencies in partnership with universities and research centers have been working to change this scenario through the development of a mechanistic-empirical method that is more compatible with the Brazilian geographic and technical-scientific realities. The first outcome of this task force is the computer program $\mathrm{MeDiNa}$, which is still under assessment. In this present study, the new flexible pavement software in Brazil (MeDiNa) was used by the Federal University of Juiz de Fora to calculate the overlay asphalt of its the ring road, aiming to recover its functional proprieties. This pavement was evaluated functionally by Computerized Continuous Visual Survey (CCVS) and tests of longitudinal cracks, and structurally by survey deflection measurements (FWD) and shaft sinking. With the data collected from the structural evaluation, the homogeneous segmentation of the stretch and the back-calculation of the data was carried out, aimed at the acquisition of needed parameters for the calculation. After the appropriate design, it was concluded that the best solution for the overlay is resurfacing along its entire length, with the use of the project's asphalt mixture with single thickness of $5.0 \mathrm{~cm}$, observing the application of the anti-reflective cracking layer in some stretches.

Keywords: Mechanistic-Empirical Method, overlay, back-calculation. 


\section{Introduction}

In a transport infrastructure system, the pavement is regarded to be the most important component, both on financial and operational issues, meaning a heritage, whose management is crucial to the total cost reduction. The conservation and maintenance of the pavements must be treated as investments, allowing an economic and social return, ensuring that the pavement maintains its functionality

The structure of a pavement undergoes a degradation and wear process, resulting in a reduction of its structural condition. Such process is due to climate change actions, the traffic movement, and physical or chemical changes of the materials. Compared to other types of structures, the deterioration velocity tends to be greater in pavements, due to their

\section{Materials and methods}

The stretch which was analysed in this study was the flexible pavement of Federal University of Juiz de Fora ring road. According to Machado (2016), its construction started in the 1960s, and since then, only one rehabilitation was carried out (in the 1991, a resurfacing was executed with approximately $4.0 \mathrm{~cm}$ of thickness). This ring road represents the main access wide exposure to weather and intense traffic (Mikolaj, et al., 2019).

Therefore, it is acceptable to state that a pavement management system is fundamental for the routine monitoring of their functional and structural conditions. This process, influences not only the maintenance and rehabilitation direct costs, but also the other fractions of the total cost, such as operating costs of vehicles, accidents, disruption of traffic, etc.

The maintenance of a pavement includes all operations which modifies, directly or indirectly, the actual pavement condition. The purpose of this practice can be either the functional return of the pavement characteristics, or the prevention of damage to its structural components, ensuring thus, an extension of its life-cycle.
Both the current method of flexible pavement design (DNER method, developed in 1996, by the Engineer Murillo de Souza), and the procedures of overlay design existent in Brazil today are, in general, based on totally empirical methods.

In view of this, the road agencies along with the universities and research centers have recently set up a task force to create a new method of pavement design, founded on a machanisticempircal method that is more suitable to technical-scientific and geographical realities. This method strives for theoretical analysis specifically for pavement mechanics, and becomes independent of the empirical parameters of materials, although it requires calibrations with experimental data. road of the campus, linking the different faculties to the central area (rectory, central library, civic square, etc.) and the southern area of Juiz de Fora to the upper city.

The staking of the road stretch was carried out taking as a base the intern-al lane of the ring. Then, over the $2,140 \mathrm{~m}$ of extension, 107 stakes were placed, with spacing of $20 \mathrm{~m}$ between them. How- ever, over the FWD surveys, the deflection measurement had to be displaced in some stretches due to the presence of a calm traffic system, which resulted in the listing of 98 stakes. With regards to shaft sinking, due to the logistical and enforcement difficulties, it was possible to implement only one shaft (in the parking lane), along all the extension (Figure 1).

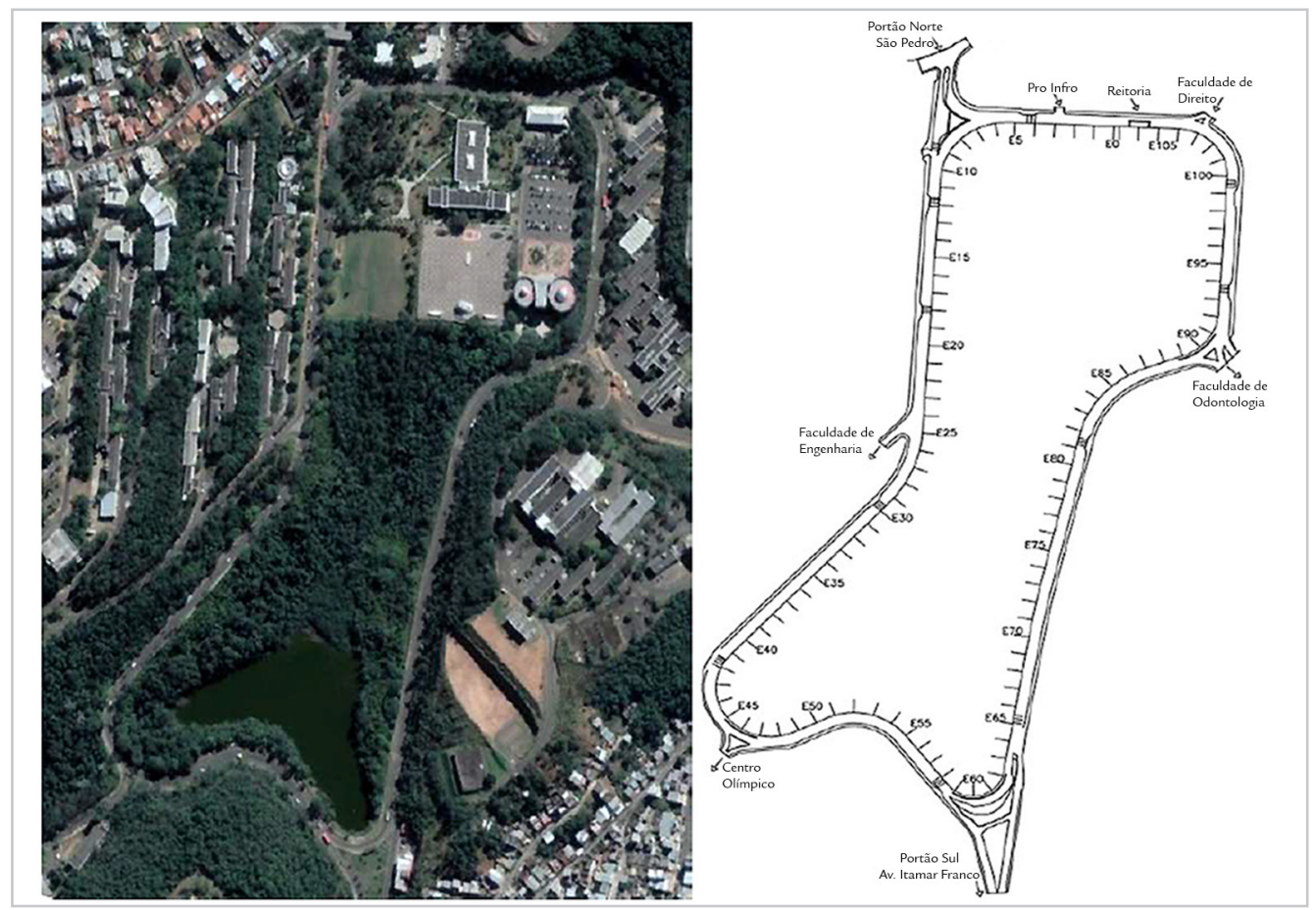

Figure 1 - Satellite imagery and schematic representation of the UFJF ring road.

As to the traffic, one survey carried out in the second semester of 2015 by UFJF Engineering Faculty, pointed out that the Average Daily Traffic on campus during working days corresponded to approximately
9000 vehicles (Machado, 2016). With this datum, and considering a traffic annual growth rate of $1 \%$, the ADT 
value becomes 9300 vehicles.

For this study, the functional evaluation was carried out through the device "Computerized Continuous Visual Evaluation" by ENGGEOTECH
Consultores de Engenharia Ltda company, using the computational software HoleHunter 4.0, drawn and designed by the same, in 2018. This software enables the record preview along with the description of the noted occurrences, while displaying a representative graphic about the relief altimetry of the road stretch, and in a satellite imagery, the covered path (Figure 2).

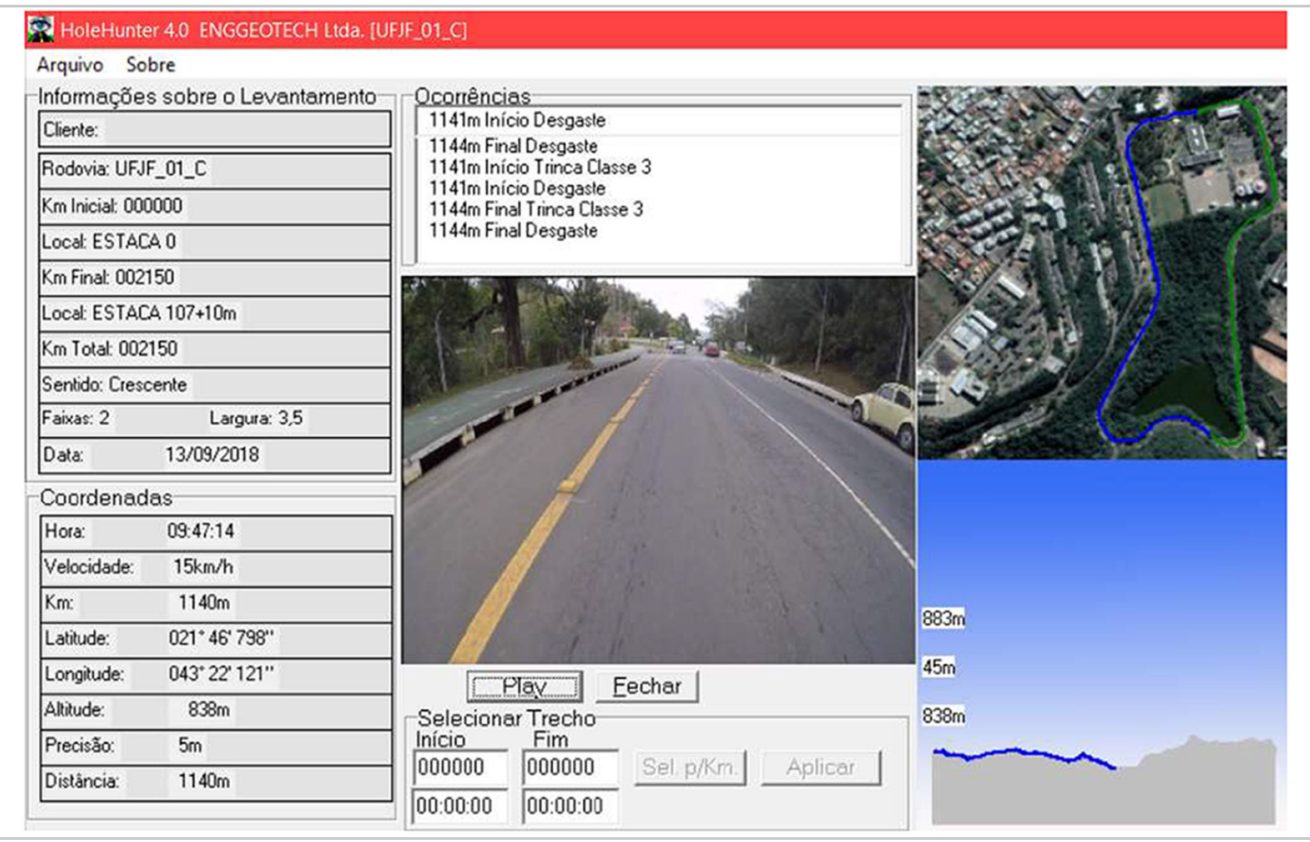

Figure 2 - HeoleHuntter software screen displaying the video record together with the listed defects, the path and the altimetry.

Although the all defects predicted in standard DNER 005/2003 (intended for overlay design by MEDINA software) have been surveyed, only the data of cracked area percentage are needed. This parameter was obtained by the sum of percentages regarding level 2 cracks (openings greater than $1.0 \mathrm{~mm}$ without erosion edges) and level 3 (openings greater than $1.0 \mathrm{~mm}$ without erosion edges), verified in situ by LVCI.

With regards to the International Roughness Index (IRI), in the survey carried out by the COPPE staff, a device was used which is suspended and utilizes the tenet of laser lightwaves for the roughness measures. This device was developed by the Cibernética company, and presents 5 laser moduli, installed in a beam connected to the vehicle's front side. The modules are linked to the central processing unit, which storages the data in a computer inside the vehicle.

In order to carry out the functional evaluation, the KUAB 8833 device, by Konsult \& Utvclinkg AB, was utilized, and the deflections were measured through nine absolute deflection transducers. These transducers, known as linear variable differential transformer (LVDTs), are placed one in the center of the plate and the other placed at $20 \mathrm{~cm}, 30 \mathrm{~cm}$,
$45 \mathrm{~cm}, 60 \mathrm{~cm}, 90 \mathrm{~cm}, 120 \mathrm{~cm}, 150 \mathrm{~cm}$ and $180 \mathrm{~cm}$ away.

With respect to soil prospection, one shaft survey of $80 \times 80 \mathrm{~cm}$ was opened in the pavement, close to stake 40, in order to collect the materials and to determine the thicknesses. The material samples collected were tested at the Juiz de Fora Technology Center Foundation, according to the procedures described in the standards for characterization tests and resilient modules.

The next step was the backcalculation. The ring road was divided into homogenous segments aiming to extend the structural parameter validity and traffic measured at some points along the entire extension, in function of the physical characteristic uniformities, degradation state and flow of traffic. The procedures were carried out according Ashto (1993), which utilize the Cumulative Difference Approach and maximum deflection.

The software utilized in this study for the back-calculation process was the BackMeDiNa, which calculates the difference between measured and calculated deflection in each sensor, with the final error measured through the deflection root mean square (RMS). Aiming to develop a project as reliable as possible, only outputs whose errors were lower than $10 \mu \mathrm{m}$ were admitted in this research.

The pavement structure input in the software corresponds to that observed in the prospection, being that the Poisson coefficients of the different layers were estimated with regard to the values usually utilized in the country, listed as follows:

- Surface: $8.0 \mathrm{~cm} / \mu=0.30$;

- Base: $10.0 \mathrm{~cm} / \mu=0.35$;

- Subbase: $20.0 \mathrm{~cm} / \mu=0.35$;

- Compacted subgrade: $40.0 \mathrm{~cm} / \mu=0.45$;

- Subgrade: thickness semiinfinite $/ \mu=0.45$;

The overlay design of UFJF ring road was carried out by software $\mathrm{Me}$ $\mathrm{DiNa}$, through the Overlay Mode of the program. In this mode, the user initially enters with information about the pavement structure, such as layer numbers, thicknesses, types of materials, resilient modulus and Poisson coefficient.

Then, the user enters with the complementary data of the existing surface, such as cracked area percentage, the IRI, milling thickness and the pavement age. The asphalt mixture, which is input in the pavement, was designed by the SUPERPAVE method, using a type of asphalt binder commonly utilized in Juiz de Fora, the CAP 50/70, produced by Refinaria Duque de Caxias (Reduc). This design 
was carried out by Neumann (2018) at UFJF Pavement Laboratory, with optimum content of $5.9 \%$.

After this step, the data about the traffic was input as follows: type of road, Average Daily Traffic (ADT); vehicle factor (VF); percentage of vehicles on project lane; growth rate; and project period. The ADT, as already presented, was established, for the first-year analy- sis (2018), as 9300 vehicles, considering $90 \%$ of saloon cars and $10 \%$ of urban buses, and an estimate of $50 \%$ of vehicle in the project lane. Table 1 summarizes the traffic data input in the software.

Table 1 - Summary of traffic data.

\begin{tabular}{c|c}
\hline \multicolumn{2}{c}{ Traffic Data } \\
\hline Type of road & Local road \\
\hline ADT (1 year) & 9300 \\
\hline $\mathrm{VF}$ & 0.095 \\
\hline $\mathrm{N}$ (1 year) & $3.22 \mathrm{e}^{+} 5$ \\
\hline \% of vehicles on project lane & 50 \\
\hline $\mathrm{N}$ (lane) & $1.61 \mathrm{e}^{+5}$ \\
\hline Growth rate $(\%)$ & 1 \\
\hline Project period & 10 \\
\hline $\mathrm{N}$ (total) & $1.69 \mathrm{e}^{+}+6$ \\
\hline
\end{tabular}

\section{Results and discussions}

\subsection{Cracked area percentage (CA\%)}

From the image collected analyses in LVCI, the percentage of areas affected by cracks of level 2 and 3 was defined. In Table 2 a summary of characteristic CA\% found is presented $(\mathrm{CA} \%=\Delta+\sigma)$, where $\Delta$ presents the arithmetic mean and $\sigma$ the sample standard deviation.

Table 2 - Characteristic Cracked Area Percentage of homogeneous segments (Author, 2018).

\begin{tabular}{|c|c|c|c|c|c|c|c|}
\hline Segment & $\Delta(\%)$ & $\sigma(\%)$ & CA \% & Segment & $\Delta(\%)$ & $\sigma(\%)$ & CA \% \\
\hline 01 & 24.20 & 15.75 & 39.95 & 05 & 5.16 & 8.34 & 13.50 \\
\hline 02 & 39.58 & 14.78 & 54.37 & 06 & 13.65 & 11.97 & 25.63 \\
\hline 03 & 25.67 & 10.11 & 35.78 & 07 & 6.25 & 6.99 & 13.24 \\
\hline 04 & 18.75 & 16.58 & 35.60 & 08 & 23.13 & 7.65 & 30.77 \\
\hline
\end{tabular}

Tables supplied by the National Agency of Land Transportation (ANTT) were consulted in order to evaluate the functional and structural states of pavement, therefore the homogenous segments $01,02,03$ and 04 were clas- sified as the "Terrible", the 06 and 08 segments as "bad", while the segments 05 and 07 were "regular".

\subsection{International Roughness Index (IRI)}

According to the usual procedure Roughness Index (IRIc), each segment of the characteristic International produced the values shown in Table 3:

Table 3 - Homogeneous Segments IRI (Author, 2018).

\begin{tabular}{l|l|l|l}
\hline \multicolumn{4}{c}{$\operatorname{IRIc}(\mathrm{m} / \mathrm{km})$} \\
\hline Segment 01 & 4.31 & Segment 05 & 2.56 \\
\hline Segment 02 & 4.16 & Segment 06 & 1.87 \\
\hline Segment 03 & 3.39 & Segment 07 & 2.70 \\
\hline Segment 04 & 4.14 & Segment 08 & 2.72 \\
\hline
\end{tabular}

The ANTT classifies the road stretch as well, with regard to its characteristic IRIs in four classes. Ac- cording to that classification, the segments 01,02 and 04 were classified as "Bad", the segment 03 as "Regular", and the segments $05,06,07$ and 08 as "Good".

\subsection{Laboratory tests}

The outcomes of laboratory tests are shown in Table 4: 
Table 4 - Summary of characterization and resilience module tests of the material used in the research.

\begin{tabular}{|c|c|c|c|c|c|c|}
\hline & Parameters & Surface & Base & Subbase & Compacted subgrade & Subgrade \\
\hline \multirow{3}{*}{$\begin{array}{l}\cdot \frac{\tilde{N}}{N} \\
\cdot \frac{\tilde{N}}{\pi} \\
\stackrel{\frac{N}{U}}{0}\end{array}$} & $4.8 \leq \mathrm{d}<2.0 \mathrm{~mm}$ & - & $8 \%$ & $12 \%$ & $1 \%$ & $1 \%$ \\
\hline & $2.0 \leq \mathrm{d}<0.42 \mathrm{~mm}$ & - & $51 \%$ & $47 \%$ & $10 \%$ & $18 \%$ \\
\hline & $\mathrm{d} \leq 0.075 \mathrm{~mm}$ & - & $18 \%$ & $19 \%$ & $77 \%$ & $52 \%$ \\
\hline \multicolumn{2}{|r|}{ Optimum moisture } & - & $12.90 \%$ & $18.30 \%$ & $21.70 \%$ & $24.60 \%$ \\
\hline \multicolumn{2}{|c|}{ Maximum density $\left(\mathrm{g} / \mathrm{cm}^{3}\right)$} & - & 1930 & 1760 & 1487 & 1451 \\
\hline
\end{tabular}

A suitable uniformity was observed for the value set found in the resilient modu- lus tests; fact evidenced by the low variation coefficient $(16 \%)$. With regards to the asphalt mixture, the resilient modulus and fatigue test outcomes are shown in Table 5 .

Table 5 - Results of resilient modulus and fatigue tests for the asphalt mixture (Author, 2018).

\begin{tabular}{c|c}
\hline Resilient Moduli (MPa) & 5963.00 \\
\hline k1 & $7.40 \mathrm{E}-11$ \\
\hline k2 & -3.3104 \\
\hline
\end{tabular}

\subsection{Backcalculation}

The estimate of resilience module seeds, which are inputs to the software, were defined according to resilient modulus test outcomes realized with the 12 samples extracted from pavement and with the samples molded in the laboratory.

Table 6 shows figures of resilient modulus obtained in backcalculation, with values corresponding to simple arithmetic means of the modulus value set, regarding the deflection bowls of each stake.

Table 6 - Modulus values obtained in Backcalculation (MPa).

\begin{tabular}{|c|c|c|c|c|c|}
\hline Segment & Surface & Base & Subbase & Compacted subgrade & Subgrade \\
\hline 1 & 6045 & 465 & 661 & 466 & 324 \\
\hline 2 & 4879 & 434 & 373 & 374 & 322 \\
\hline 3 & 9115 & 715 & 874 & 707 & 396 \\
\hline 4 & 3994 & 497 & 432 & 289 & 267 \\
\hline 5 & 3805 & 457 & 682 & 433 & 321 \\
\hline 6 & 4024 & 419 & 413 & 318 & 299 \\
\hline 7 & 4825 & 545 & 609 & 396 & 266 \\
\hline 8 & 5197 & 367 & 276 & 241 & 205 \\
\hline
\end{tabular}

Observing the outcomes, it was found that the surface of the flexible pavement achieved a high mean resilient modulus (5235.5 $\mathrm{MPa})$, but lower than the module from laboratory

\subsection{Overlay design}

In the overlay design of homogeneous segments, all data of the pavement structure were initially input with its physical parameters considered the same test. Besides this, the data of modulus obtained for the Compacted subgrade layers showed, in the majority of cases, higher values than those found in base and subbase layers. With regard

for all homogeneous segments.

After this step, in which all necessary data were input, the overlay calculation was automatically executed. Table 7 shows to standard deviation values and the variation coefficients among the deflection bowls, the procedure did not result in significant values, symbolizing low dispersion of values.

the obtained thicknesses for each one of the 8 segments, as well as the cracked forecasted area percentage at the end of the project period. 
Table 7 - Results obtained on the overlay design of all homogeneous segments for 50\% of traffic in the project lane (Author, 2019).

\begin{tabular}{c|c|c|c|c|c}
\hline Segment & $\begin{array}{c}\text { Overlay Thickness } \\
(\mathrm{cm})\end{array}$ & $\begin{array}{c}\text { CA\% in the project } \\
\text { period end }\end{array}$ & Segment & $\begin{array}{c}\text { Overlay Thickness } \\
(\mathrm{cm})\end{array}$ & $\begin{array}{c}\text { CA\% in the project } \\
\text { period end }\end{array}$ \\
\hline Segment 01 & 5.0 & $6.8 \%$ & Segment 05 & 5.0 & $6.8 \%$ \\
\hline Segment 02 & 5.0 & $8.3 \%$ & Segment 06 & 5.0 & $9.9 \%$ \\
\hline Segment 03 & 5.0 & $5.4 \%$ & Segment 07 & 5.0 & $7.0 \%$ \\
\hline Segment 04 & 5.0 & $9.8 \%$ & Segment 08 & 5.0 & $9.4 \%$ \\
\hline
\end{tabular}

It has also been noted that, for all the segments, the MeDiNa software indicated the overlay minimum thickness $(5.0 \mathrm{~cm})$. This fact was rectified by forecasted percentages of the cracked area, which presented figures quite bellow of the limit of $30 \%$ (accepted by the software for the last project month).

In order to evaluate the upper limits of the project thicknesses, a new design was carried out considering $100 \%$ of the traffic passing in the project lane, which consists in the most critical situation. Besides this, in two stretches of the ring (stakes 6 to 9 and 59 to 62 ) the right lane joins the left lane, and therefore, in these cases, it would be the correct analysis to do. Table 8 shows the outcomes.

Table 8 - Results obtained on the overlay design of all homogeneous segments for $100 \%$ of traffic in the project lane (Author, 2019).

\begin{tabular}{c|c|c|c|c|c}
\hline Segment & $\begin{array}{c}\text { Overlay Thickness } \\
(\mathrm{cm})\end{array}$ & $\begin{array}{c}\text { CA\% in the project } \\
\text { period end }\end{array}$ & Segment & $\begin{array}{c}\text { Overlay Thickness } \\
(\mathrm{cm})\end{array}$ & $\begin{array}{c}\text { CA\% in the project } \\
\text { period end }\end{array}$ \\
\hline Segment 01 & 5.0 & $18.8 \%$ & Segment 05 & 5.0 & $18.8 \%$ \\
\hline Segment 02 & 5.0 & $24.2 \%$ & Segment 06 & 9.4 & $28.4 \%$ \\
\hline Segment 03 & 5.0 & $14.1 \%$ & Segment 07 & 5.0 & $19.6 \%$ \\
\hline Segment 04 & 9.4 & $29.2 \%$ & Segment 08 & 8.8 & $29.5 \%$ \\
\hline
\end{tabular}

As can be seen, only 3 segments presented different thicknesses than previously calculated. However, all segments show a significant rise in the percentage values of cracked area. The software MeDiNa does not analyse the propagation of cracks from the old to the new pavement, whereby the user suggests alternatives to prevent or to delay this process. Considering this scenario, proposed was a new design for the segments with overlay thicknesses higher than $5 \mathrm{~cm}$ and/or with a cracked area higher than $20 \%$ (in the situation which was taken into account $100 \%$ of traffic in the project lane).

In this design, the execution of one layer to reduce propagation of cracks between the new and old surface was considered. The chosen material was an asphalt mixture particularly designed to absorb the stress, with $1.5 \mathrm{~cm}$ of thickness, resilient modulus of $3000 \mathrm{MPa}$, Poisson Coefficient of 0.25 and specific mass of $2.4 \mathrm{~g} / \mathrm{cm}^{3}$. The obtained outcomes are shown in Table 9.

Table 9 - Overlay outcomes of segment 02, 04, 06 and 08 with layer to reduce propagation of cracks for $100 \%$ of traffic in the lane (Author, 2019).

\begin{tabular}{c|c|c}
\hline Segment & Overlay thickness $(\mathrm{cm})$ & CA\% in the project period end \\
\hline Segment 02 & 5.0 & $15.6 \%$ \\
\hline Segment 04 & 5.0 & $19.0 \%$ \\
\hline Segment 06 & 5.0 & $19.0 \%$ \\
\hline Segment 08 & 5.0 & $18.2 \%$ \\
\hline
\end{tabular}

With these three incurred simulations, it was observed that the best solution of overlay for the UFJF ring road flexible

\section{Conclusion}

In this study, a research was carried out regarding a method of flexible pavement maintenance, known as overlay, which consists of the implementation of a new asphalt mixture over the existing surface, aiming at the re-establishment of certain functional properties, as well prevention of future damages.

The outcomes of international pavement is the execution of a resurfacing with a layer of unique thickness of $5.0 \mathrm{~cm}$ (asphalt mixture), besides the application of a layer to reduce propagation of cracks in the stretches corresponding to segments 02, 04, 06 and 08. 
affected areas.

The high values of the cracked area verified by the method are related to prolonged exposure of the structure to dynamic loadings, enforced by vehicles, and to adverse weather effects, caused by climatic agents, as well as by the road's own chemical properties inherent to the materials.

Looking at the high values of effective elastic modulus and of UFJF ring road asphalt surface resilient moduli, it can be said that, despite advanced age, the ring still has a good capacity for supporting the exposure demands.

The overlay design based on the New Brazilian Mechanistic-Empirical Method was carried out in three situations: 1$)$ asphalt material overlay considering $50 \%$ of the traffic in the project lane; 2) asphalt material overlay considering $100 \%$ of the traffic in the project lane; and 3) asphalt material overlay and layer to reduce propagation of cracks in some segments, considering $100 \%$ of the traffic in the project lane.

In the first situation, the overlay minimum thickness, allowed by software $\mathrm{MeDiNa}(5.0 \mathrm{~cm})$, was determined for all the analyzed segments, and the forecasted cracked area percentages for the last month of analysis were between $5.4 \%$ and $9.9 \%$. These outcomes allowed to conclude that those thicknesses could be even lower if the cracked area limit of $30 \%$ was taken into account. Nevertheless, the overlay execution with thicknesses inferior to $5.0 \mathrm{~cm}$ is neither usual nor recommended by DNIT.

In order to establish an upper limit for the overlay thicknesses in a critical scenario, it was decided to carry out the design according to the second situation (whose returned values were quite high for the overlay thicknesses in the segments 02, 04, 06 and 08, while maintaining the other thicknesses at $5.0 \mathrm{~cm}$ ). The percentages of the forecasted cracked area rose significantly for all the segments, with emphasis in the segments 02,04,06 and 08 , whose values exceeded $24 \%$ of cracked area.

The even segments become evident, as they are those that require more attention by the user. With this in mind and considering the fact that MeDiNa software does not analyze the propagation of cracks from the old to the new pavement, the design was developed regarding a third situation. Due to presence of the crack propagation layer, the overlay thicknesses of those segments went back to having the minimum value of $5.0 \mathrm{~cm}$, and its forecasted cracked areas presented values inferior to $20 \%$.

Considering the simulations made, it is possible to conclude that the best solution for the UFJF road ring pavement overlay is to adopt a resurfacing with $5.0 \mathrm{~cm}$ of the project asphalt mixture $\left(\mathrm{M}_{\mathrm{R}}=5963 \mathrm{MPa}\right)$ throughout the entire extension, paying attention to the utilization of an anti-crack propagation layer with $1.5 \mathrm{~cm}$ of thickness $\left(\mathrm{M}_{\mathrm{R}}=3000 \mathrm{MPa}\right)$ in the segments $02,04,06$ and 08 .

\section{References}

AASHTO. AASHTO guide for design of pavement structures. Washington, DC: AASHTO, 1993. 624 p.

AGÊNCIA NACIONAL DE TRANSPORTES TERRESTRES. Recurso de Desenvolvimento Tecnológico RDT: procedimento para levantamento visual contínuo informatizado (LVCI) pelo método da varredura. Relatório Final. Nova Lima: ANTT, 2017.

AMERICAN SOCIETY FOR TESTING AND MATERIALS. ASTM D5858: Standard guide for calculating in situ equivalent elastic moduli of pavement materials using layered elastic theory. West Conshohocken, PA: ASTM, 2015.7p.

BALBO, J. T. Pavimentação asfáltica: materiais, projeto e restauração. São Paulo: Oficina de Textos, 2007. 560p.

BERNUCCI, L. B.; MOTTA, L. M. G.; CERATTI, J. A. P.; SOARES, J. B. Pavimentação asfáltica: formação básica para engenheiros. 3. ed. Rio de Janeiro: PETROBRAS: ABEDA, 2008. 501p.

BEZERRA NETO, R. S. Análise comparativa de pavimentos dimensionados através dos métodos empírico do DNER e mecanístico e proposta de um catálogo simplificado de pavimentos para a região de Campo Grande (MS). 2004. 169f. Dissertação (Mestrado em Engenharia de Transportes) - Escola de Engenharia, Universidade de São Paulo, São Carlos/SP, 2004.

DANIELESKI, M. L. Proposta de metodologia para avaliação superficial de pavimentos urbanos: aplicação à rede viária de Porto Alegre. 2004. 170f. Dissertação (Mestrado em Engenharia Civil) - Escola de Engenharia, Universidade Federal do Rio Grande do Sul, Porto Alegre, 2004.

DEPARTAMENTO NACIONAL DE ESTRADAS DE RODAGEM. Guia de redução de acidentes com base em medidas de engenharia de baixo custo. Rio de Janeiro: DNER, 1998. 140p.

DEPARTAMENTO NACIONAL DE INFRAESTRUTURA DE TRANSPORTES. Norma DNIT 005/2003-PRO: defeitos nos pavimentos flexíveis e semi-rígidos - terminologia. Rio de Janeiro: DNIT, 2003a. 12p.

Norma DNIT 009/2003-PRO: avaliação subjetiva da superfície de pavimentos flexíveis e semi-rígidos procedimento. Rio de Janeiro: DNIT, 2003b. 6p.

Manual de estudos de tráfego. Rio de Janeiro: DNIT, 2006. 310p. (Publicação IPR - 723).

FRANCO, F. A. C. P. Método de dimensionamento mecanístico-empírico de pavimentos asfálticos -SISPAV. 2007. 294f. Tese (Doutorado em Engenharia Civil) - Universidade Federal do Rio de Janeiro, Rio de Janeiro, 2007.

FRANCO, F. A. C. P.; FRITZEN, M. A.; MOTTA, L. M. G. BackMeDiNa. v.1.1.0. Rio de Janeiro: COPPE/UFRJ, 2018a. Programa computacional.

MeDiNa. v.1.1.1.0. Rio de Janeiro: COPPE/UFRJ, 2018b. Programa computacional.

FRITZEN, M. A. Desenvolvimento e validação de função de transferência para previsão do dano por fadiga em pavimentos asfálticos. 2016. 262f. Tese (Doutorado em Engenharia Civil) - Universidade Federal do Rio de Janeiro, Rio de Janeiro, 2016.

FRITZEN, M. A.; MOTTA, L. M. G. Levantamento deflectométrico com o uso do FWD (Falling Weight 
Deflectometer) no anel viário principal do campus da Universidade Federal de Juiz de Fora: Relatório Final. Rio de Janeiro: COPPE/UFRJ, 2018. 20p.

GONÇALVES, F. P. O diagnóstico e a manutenção dos pavimentos (notas de aula). Passo Fundo, RS: Universidade de Passo Fundo, 1999. 75f.

MACHADO, T. F. O. Estudo de soluções para reforço do pavimento do anel viário da Universidade Federal de Juiz de Fora. 2016. 91f. Trabalho de Conclusão de Curso (Graduação em Engenharia Civil) - Universidade Federal de Juiz de Fora, Juiz de Fora, 2016.

MIKOLAJ, J.; REMEK, L.; MARGORINOVA, M. Road user effects related to pavement degradation based on the highway development and management tools. Transportation Research Procedia, v. 40, p. 1141-1149, 2019.

MORAES, C. G. Análise de bacias deflectométricas obtidas por 4 equipamentos do tipo falling weight deflectometer (FWD). 2015. 283f. Dissertação (Mestrado em Engenharia Civil) - Universidade Federal do Rio de Janeiro, Rio de Janeiro, 2015.

NEUMANN, G. P. Um exemplo de dosagem de concreto asfáltico por meio da metodologia SUPERPAVE. 2018. 61f. Trabalho de Conclusão de Curso (Graduação em Engenharia Civil) - Universidade Federal de Juiz de Fora, Juiz de Fora, 2018.

SOUZA JÚNIOR, J. G. Aplicação do novo método de dimensionamento de pavimentos asfálticos a trechos de uma rodovia federal. 2018. 219f. Dissertação (Mestrado em Engenharia Civil) - Universidade Federal do Rio de Janeiro, Rio de Janeiro, 2018.

Received: 24 July 2019 - Accepted: 25 April 2020. 